\title{
ДИНАМИК НӨХЦӨЛД УСАН УУСМАЛААС Cr(VI)-ЫГ БИОСОРБЦЛОХ ПРОЦЕССЫН КИНЕТИКИЙН СУДАЛГАА
}

\author{
А.Алтангэрэл, С.Даваасурэн \\ Химийн тэнхим, Байгалийн ухааны салбар, Монгол улсын их сургууль, \\ Улаанбаатар хот, Монгол улс \\ Цахим шуудан: dakamuis@yahoo.com
}

Редакичид ирүҮлсэн: 2016.02.15

Товч агуулга: ХҮрээлэн буй орчны чухал асуудльнн нэг нь усан орчин дахь бохирдуулагч, хортой хүнд металльг зайлуулах явдал юм. Хүнд металл болон тэдгээрийн нэгдлүҮдийг зайлуулах физик, хими, биологийн олон төрлийн аргууд байдгаас биосорбиьын арга нь эдийн засгийн хувьд хямд, нүсэр тоног төхөөрөмж шаарддаггүй, хүрээлэн буй орчинд ээлтэй, бүтээмж өндөртэй зэрэг давуу талуудтай. Энэхүу судалгаанд липтон иайны хаягдал биомассаар усан орчноос Cr(VI)-blг биосорбилох туршилтыг динамик нөхиөлд явуулж, процессын зохистой нөхилийг биосорбент материалын үеийн зузаан, урсгальын хурд, $\mathrm{Cr}(V I)$ ын анхны концентрацаас хамааруулан сонгож, биосорбцын кинетикийг тодорхойлох зорилго тавьсан. Туршилтын дүнгээс харахад липтон ияайны хаягдал биомассаар Cr(VI)-ыл биосорбилох процесс нь Cr(VI)-ын анхны концентрации 10 мг/л, уусмалын урсгалын хурд 1 мл/мин, биосорбент материалын үеийн зузаан 10 см үед хамгийн сайн явагдаж байв. Усан уусмалаас Cr(VI)-ыг биосорбилох прочесс нь рsеиdо-II эрэмбийн кинетик зүй тогтлоор явагдаж байгааг тогтоов.

Tүлхүур үг: биосорби, динамик нөхиөл, Cr(VI), липтон цุайны биомасс, кинетикийн судалгаа

\section{ОРШИЛ}

Манай орны хувьд сүүлийн жилүүдэд хот суурин газарт хүн амын нягтрал ихсэж, аж үйлдвэр, түүний дотор эрчим хүч, барилга, эрдэс түүхий эдийг олборлох болон боловсруулах үйлдвэрийн тоо олширч байгаа билээ [1]. Эдгээр үйлдвэрүүд нь химийн олон төрлийн бодисыг хэрэглэснээр үйлдвэрийн бохир усан дахь хорт бодисын агуулга зөвшөөрөгдөх хэмжээнээсээ давснаас шалтгаалан байгаль орчны тэнцвэрт байдал алдагдаж байгааг судлаачид тогтоогоод байна. Ийм бохирдолтын нэг нь антропоген хүчин зүйлсээс үүдэлтэй усан орчинд хуримтлагдаж байгаа хүнд металлууд, тухайлбал хром, хар тугалга, кадми, хүнцэл, мөнгөн ус юм [2].

Орчин үед усан уусмал дахь хүнд металлын бохирдолтыг багасгахад тэдгээрийг шингээх сонгомол шинж чанартай, байгалийн болон ахуйн хаягдал материалыг хэрэглэдэг биосорбцын аргыг өргөн хэрэглэх болжээ [2].

Биосорбц нь ердийн физик химийн процесст үндэслэгдсэн, идэвхгүй 
биомассын тусламжтайгаар их хэмжээний шингэрүүлсэн уусмал буюу бохир уснаас хүнд металлыг шингээн зайлуулах арга юм [3]. Биосорбцын процессыг тасралтгүй колонкоор явуулах нь үйлдвэрийн хувьд илүY тохиромжтой тул эрдэмтэд динамик нөхцөл дэх биосорбцын процесст нөлөөлөх биосорбент материалын үеийн зузаан, колонк руу уусмал нэвтрэх хурд, уусмалын анхны концентраци, биосорбентын үед тухайн ионы байх хугацаа зэрэг хүчин зүйлийн зохистой утгыг тогтоох,

\section{СУДАЛГААНЫ АРГА АРГАЧЛАЛ}

Судалгааны материал: Динамик нөхцөлд усан уусмалаас $\mathrm{Cr}(\mathrm{VI})$-ыг биосорбцлох туршилтыг 1.3 см диаметртэй, 28 см өндөртэй шилэн колонкод тасалгааны температурт явууллаa. Судалгаанд хэрэглэсэн липтон цайны биомассыг хандлагдахгүй болтол усаар угааж дараа нь нэрсэн усаар 2 удаа зайлан, тасалгааны температурт хатаах дарааллаар туршилтанд бэлтгэсэн.

Уусмал дахь $\mathrm{Cr}(\mathrm{VI})-ы н$ агуулгыг тодорхойлох: Сул хүчиллэг орчинд $\mathrm{Cr}(\mathrm{VI})$ нь 1,5 дифенилкарбазидтай харилцан үйлчилж, улаан ягаан өнгийн комплекс нэгдэл үүсгэдэг урвал дээр үндэслэсэн спектрофотометрийн аргаар уусмал дахь $\mathrm{Cr}(\mathrm{VI})$-ын агуулгыг тодорхойлсон. Аргын мэдрэх чадвар 200 мкг $\mathrm{Cr}(\mathrm{VI}) /$ л, $\mathrm{S}_{\mathrm{r}}=0.02$ байдаг $[1,4]$. Жиших муруйн регрессийн коэффициент $\mathrm{R}^{2}=0.9986$ байлаа.

Электрон микроскопийн арга: Биосорбент материалыг вакуум орчинд сайтар хатаасны дараа тухайн дээжний цахилгаан дамжуулалтыг хангалттай хэмжээнд аваачих, гадаргуугийн дохиог ихэсгэх зорилгоор алтны нимгэн үеэр бүрж, шинжилгээнд дээжийг бэлтгэсэн. Дээжийг 0.5-40 кЭв энергитэй электроны урсгалаар бөмбөгдөн, электрон дээжийн гадаргуугийн харилцан үйлчлэлийн дүнд үүсэх дундын улмаар биосорбцын тэнцвэр, кинетикийг биосорбент сорбатын хоорондох масс шилжилт, диффузын процессыг харгалзан тооцоолох судалгааг түлхүү хийж байна [2, $3]$.

Иймд бид динамик нөхцөлд усан уусмалаас $\mathrm{Cr}(\mathrm{VI})$-ыг хаягдал биомассаар сорбцлох зохистой нөхцлийг сонгож, биосорбцын процессын кинетикийг тодорхойлж тогтоох зорилгоор энэХүҮ судалгааны ажлыг хийлээ.

болон сарнисан электронуудын дохиог бүртгэн дээжийн гадаргуугийн дүрсийг буулгасан. Биосорбентын гадаргуугийн дүрсийг Nikkiso фермийн Semtrae miniSM3000 маркийн электрон микрскопоор авлаа.

Рентгенфлуоресценцийн спектрометрийн арга: Үнсжүүлсэн 1.2 г дээжийг $\mathrm{LiB}_{2} \mathrm{O}_{4}$ ба $\mathrm{Li}_{2} \mathrm{~B}_{4} \mathrm{O}_{7}$-ын 6 г холимогтой хольж, $1150^{\circ} \mathrm{C}$ температурт хайлуулж бэлтгэн, PANalytical фермийн AXIO маркийн рентгенфлуоресценцийн спектрометрээр хэмжиж, биосорбент материал липтон цайны хаягдал дахь макро ба микро бүрэлдэхүүн хэсгийн агуулгыг тодорхойллоо.

Усан уусмалаас динамик нөхцөлд Cr(VI)-ыг биосорбцлох: Усан уусмалаас $\mathrm{Cr}(\mathrm{VI})$-ыг динамик нөхцөлд липтон цайны биомассаар биосорбцлох туршилтыг уусмалын анхны концентраци (5- 30 мг/л), колонк руу нэвтрэх уусмалын хурд (0.5 - 2.5 мл/мин), колонк дахь биосорбентын үеийн зузаан $(4,6,8,1012$ см) зэрэг хүчин зүйлээс хамааруулан явууллаа.

Биосорбентод шингээгдэх металлын хэмжээг, харьцангуй хуурай биосорбентын нэгж массд шингээгдэх металлын хэмжээ буюу биосорбцын багтаамж (1)-ээр илэрхийлдэг $[1,5,6]$. 


$$
q=\frac{\left(C_{0}-C_{f}\right) \cdot V}{m}
$$

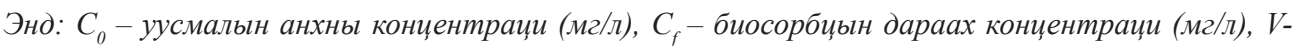
уусмалын эзэлхүҮн (мл), m- биосорбентын масс (2), $q$ - биосорбцын багтаамж, (мг/г)

Динамик нөхцөл дэх биосорбцын кинетикийн судалгаa: Биосорбцын кинетикийг судлах нь онол практикийн чухал ач холбогдолтой. Биосорбцын механизм, түүний үр ашгийг тодорхойлохын тулд туршилтын дүнг үндэслэн кинетик тооцоо хийдэг $[8,9]$.

Биосорбцын хурд нь фазуудын нийлсэн гадаргуу дахь бодисын диффузын хурд, температур, процессыг явуулж байгаа арга зэргээс хамаардаг. Судлаачид биосорбцын кинетикийг тайлбарласан онол, туршилтын

$$
\frac{d q}{d t}=k_{1}\left(q_{e}-q\right)
$$

Концентраци, хугацааны хамаарлыг гаргахын тулд дифференциал тэгшитгэлийг интегралчлах шаардлагатай байдаг. Иймд

$$
\ln \left(q_{e}-q\right)=\ln q_{e}-k_{1} t
$$

дээрх тэгшитгэлийг $t=0, q=0$ ба $t=t, q=q_{e}$ гэсэн нөхцөлд интегралчилбал тэгшитгэл

(3) хэлбэртэй болно. гаргаснаас хүнд металлын биосорбцын процесст pseudo-I, pseudo-II эрэмбийн кинетик тэгшитгэлийг хэрэглэх нь тохиромжтой болохыг судлаачид тогтоожээ $[7,10,11]$.

\section{Pseudo-I эрэмбийн кинетик} тэгшитгэл: Биосорбцын багтаамжаас хамаарсан pseudo-I эрэмбийн кинетик тэгшитгэлийг (2) байдлаар бичиж болно [8, $10,12,14]$.

Энд: $k_{1}$ - pseиdo-I эрэмбийн урвалын хурдны тогтмол (1/мин), $q_{e}-$ биосорбияын тэнцвэрийн багтаамж (мг/2), q- ххугацаан дахь биосорбиьын багтаамж (мг/2)

Дээрх тэгшитгэлийг үндэслэн $\ln \left(q_{e}-q\right)=f(t) \quad$ хамаарлын график байгуулан, графикаaс pseudo-I эрэмбийн хурдны тогтмолыг тооцоолох боломжтой юм.

$$
\frac{d q}{d t}=k_{2}\left(q_{e}-q\right)^{2}
$$

Энэ тэгшитгэлийг $t=0, q=0$ ба $t=t, q=q_{e}$ гэсэн нөхцөлд интегралчилбал тэгшитгэл

$$
\frac{t}{q}=\frac{t}{q_{e}}+\frac{1}{k_{2} q_{e}^{2}}
$$

Энд: $k_{2}$ - pseudo-II эрэмбийн урвальлн хурдны тогтмол (г/(мг×мин)), $q_{e} \quad-$ биосорбцын тэнцвврийн багтаамж (мг/2), $q-t$ хугацаан дахь биосорбиььн багтаамж $(\mathrm{Ma} / 2)$

\section{Pseudo-II эрэмбийн кинетик} тэгшитгэл: Биосорбцын багтаамжид үндэслэн pseudo-II эрэмбийн кинетик тэгшитгэлийг дараaх хэлбэрээр бичиж болно $[10,12,14]$.

(5) хэлбэртэй болно:

Pseudo-II эрэмбийн хурдны тогтмолыг $t / q=f(t)$ шугаман хамаарлын график байгуулж, графикаас тооцооны аргаар тодорхойлж болно. 


\section{ТУРШИЛТЫН УР ДУН}

Биосорбент материалын рентгенфлуоресценцийн шинжилгээ

Судалгаанд хэрэглэсэн липтон цайны биомассын органик биш макро болон микро бүрэлдэхүүн хэсгийн агуулгыг тогтоох зорилгоор рентгенфлуоресценцийн шинжилгээг Геологийн Төв Лабораторт хийлгэлээ. Шинжилгээний дүнг хүснэгт 1-д үзүүлэв.

ХУснэгт 1

Липтон ияайны биомассын органик бии макро, микро компонентынн агуулга

\begin{tabular}{|c|c|c|c|c|c|c|c|c|c|c|c|}
\hline \multicolumn{10}{|c|}{ Макрокомпонентын агуулга, \% } \\
\hline $\mathrm{SiO}_{2}$ & $\mathrm{TiO}_{2}$ & $\mathrm{Al}_{2} \mathrm{O}_{3}$ & $\mathrm{Fe}_{2} \mathrm{O}_{3}$ & $\mathrm{MnO}$ & $\mathrm{MgO}$ & $\mathrm{CaO}$ & $\mathrm{Na}_{2} \mathrm{O}$ & $\mathrm{K}_{2} \mathrm{O}$ & $\mathrm{P}_{2} \mathrm{O}_{5}$ & $\mathrm{~F}$ & Чийг \\
\hline 7.65 & 0.10 & 5.57 & 1.22 & 1.10 & 6.61 & 32.24 & 0.98 & 2.11 & 11.53 & $<0.05$ & 28.47 \\
\hline \multicolumn{10}{|c|}{ Микрокомпонентын агуулга, мг/кг } \\
\hline $\mathrm{Ba}$ & $\mathrm{Cr}$ & $\mathrm{Cu}$ & $\mathrm{Ga}$ & $\mathrm{Ni}$ & $\mathrm{Pb}$ & $\mathrm{Rb}$ & $\mathrm{Sr}$ & $\mathrm{Sc}$ & $\mathrm{Zn}$ & & \\
\hline 832 & 84 & 903 & 4 & 149 & 23 & 24 & 1025 & 18 & 11748 & & \\
\hline
\end{tabular}

Хүснэгт 1-ээс харахад липтон цайны хаягдал биомассд $\mathrm{CaO}(32.24 \%), \mathrm{P}_{2} \mathrm{O}_{5}$ (11.523\%), $\mathrm{SiO}_{2}(7.65 \%), \mathrm{MgO}(6.61 \%)$, $\mathrm{Al}_{2} \mathrm{O}_{3}(5.57 \%)$ тус тус агуулагдаж байна. Иймээс усан уусмалд агуулагдах хромын $\mathrm{CrO}_{4}^{2-}, \mathrm{HCrO}_{4}^{-}$анионуудтай биосорбент материалд агуулагдах кальци ба магнийн ион харилцан үйлчлэлд орох боломжтой юм. Микрокомпонентоос Zn (11748 мг/кг), $\mathrm{Sr}(1025$ мг/кг), Cu (903 мг/кг), Ва (832 мг/ кг) тус тус агуулагдаж байлаа.

Усан уусмалаас $\mathrm{Cr}(\mathrm{VI})$-ыг биосорбцлох зохистой нөхцлийг тодорхойлох
Биомассын үеийн зузааны нөлөө: Липтон цайны биомассаар усан уусмалаас $\mathrm{Cr}(\mathrm{VI})$-ыг биосорбцлох туршилтыг уусмалын анхны концентраци 10 мг/л, уусмал нэвтрэх хурд 1 мл/мин, биомассын үеийн зузаан 4, 6, 8, 10 см, 12 см болон тасалгааны температурт явууллаа. Биосорбцын үед уусмалд үлдсэн $\mathrm{Cr}(\mathrm{VI})$ ын агуулгыг 20 минут тутамд тодорхойлж байв. Туршилтын дүнг биосорбцын дараах уусмалын концентраци ба уусмалын анхны концентрацын харьцаа (C/C0), хугацааны хамаарлаар зураг 1-д үзүүллээ.

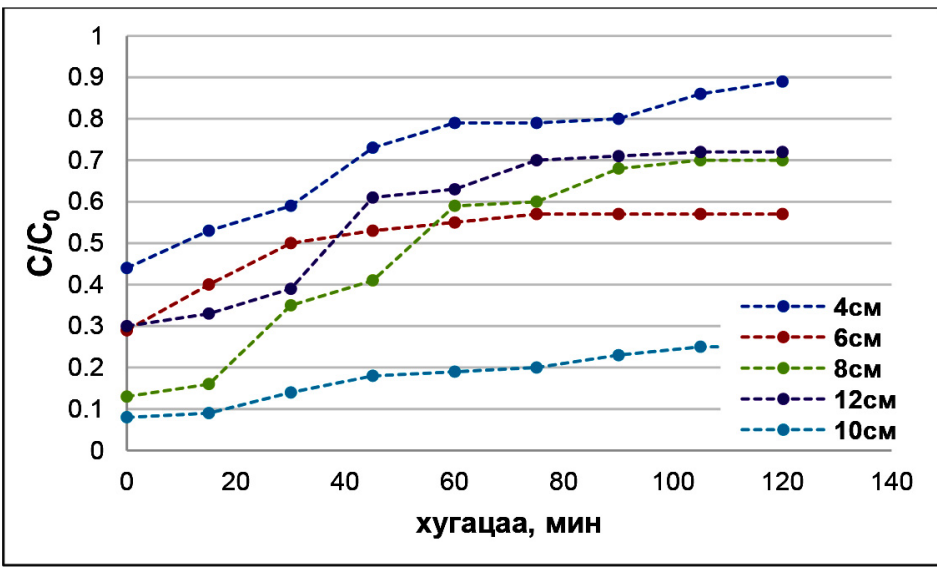

Зураг.1. Биомассын үеийн зузаан ялгаатай үед $C / C_{0}$ ба хугацааны хамаарал $\left(C_{0}=10 \mathrm{Mz} / \mathrm{s}, v=1 \mathrm{Mr} / \mathrm{мuн}, \theta=20-25^{\circ} \mathrm{C}\right)$ 
Зураг 1-ээс харахад туршилтын эхний 15 минутад концентрацын харьцаа аажим ихсэж, туршилтын дунд үед огцом өсөж, харин туршилтыг явуулснаас хойш 60 минутаас эхлээд концентрацын харьцаа тогтмолжиж байв. Энэ нь сорбат биосорбентод шингээгдх процесс туршилтыг явуулснаас хойш ойролцоогоор 60 минутын дотор эрчимтэй явагдаж байгааг харуулж байна. Биосорбент материалын үеийн зузаан ихсэхэд сорбцлогдсон бодисын хэмжээ аажим ихсэж байгааг биосорбентын үеийн зузаан ихсэхэд, биосорбентын идэвхтэй хэсэг рүY металл ионы шилжилт ихэсдэгтэй холбоотой гэж үзлээ. Туршилт явуулснаас хойш 60 минутын дараа биосорбцлогдсон бодисын хэмжээ дундажаар 99.2-99.5\% байв. Иймээс биосорбцын туршилтын 60 минутаас системд биосорбент - металл ион гэсэн хөдөлгөөнт тэнцвэр тогтсон гэж үзэж байна. Биосорбентын үеийн зузаан $10 \mathrm{~cm}$ үед эргэлтийн муруйн налуу буурч байгаа нь үеийн зузаан өсөхөд масс шилжилтийн бүс тэлж байгаатай холбоотой юм [2]. Иймд дараагийн туршилтанд биосорбент материалын үеийн зузааныг 10 см байх нь тохиромжтой гэж үзэв.

Уусмалын анхны концентрацын нөлөө: Усан уусмалаас $\mathrm{Cr}(\mathrm{VI})$-ыг биосорбцлоход уусмал дахь металл ионы анхны концентрацын нөлөөг судлахын тулд уусмалын анхны концентрацыг 5 -30 мг/л-ийн хооронд өөрчилж туршилтыг тасалгааны температурт явууллаа. Туршилтын үр дүнг Зураг 2-т нэгтгэн үзүүллээ.



Зураг.2. Уусмальн анхны концентраци ялгаатай уед С/Со хугацуааны хамаарал $\left(h=10 \mathrm{~cm}, v=1 \mathrm{Mr} / \mathrm{мuн,}, \theta=20-25^{\circ} \mathrm{C}\right)$

Туршилтын дүнгээс харахад уусмал дахь $\mathrm{Cr}(\mathrm{VI})$-ын анхны концентраци 5 - 30 мг/л болж ихсэхэд биосорбц эхний 30 минутанд эрчимтэй явагдаж, хромын концентраци 0.043-0.085 мг/л болж буурсан байлаа. Туршилтыг явуулснаас хойш 60 минутын дараа концентрацын харьцаа харьцангуй тогтмолжиж байгаа нь биосорбент материал сорбатаар ханаж байгааг харуулж байгаа юм. Уусмал дахь $\mathrm{Cr}(\mathrm{VI})$-ын концентраци ихсэхэд концентрацын харьцаа ихсэж, харин биосорбцлогдсон $\mathrm{Cr}(\mathrm{VI})$-ын хэмжээ багасаж байна. Учир нь биосорбент материалын үеийн зузаан өөрчлөгдөхгүй байгаа учир систем дэх биосорбентын идэвхтэй төвийн тоо тогтмол бөгөөд түүнд сорбцлогдох $\mathrm{Cr}(\mathrm{VI})$-ын хэмжээ бага байгаа юм [3, 15]. Харин уусмал дахь $\mathrm{Cr}(\mathrm{VI})-\mathrm{ын}$ 
агуулга бага үед концентрацын харьцаа бага байна. Энэ нь биосорбентын бүх идэвхтэй хэсгүүдтэй металлын ион бүрэн харилцан үйлчилж байгаатай холбоотой гэж үзэж байна. Иймд уусмал дахь $\mathrm{Cr}(\mathrm{VI})-$ ын концентраци 10 мг/л үед биосорбцын туршилтыг явуулах нь тохиромжтой гэж үзлээ.
Уусмал нэвтрэх хурдны нөлөө: Динамик нөхцөл дэх биосорбцын процессын чухал хүчин зүйлийн нэг бол уусмал нэвтрэх хурд юм. Усан уусмалаас $\mathrm{Cr}(\mathrm{VI})$-ыг биосорбцлоход нэвтрэх хурдыг 0.5 мл/мин - 2.5 мл/мин болгон өөрчилж туршилтыг явуулсан. Туршилтын дүнг зураг 4-д үзүүлэв.

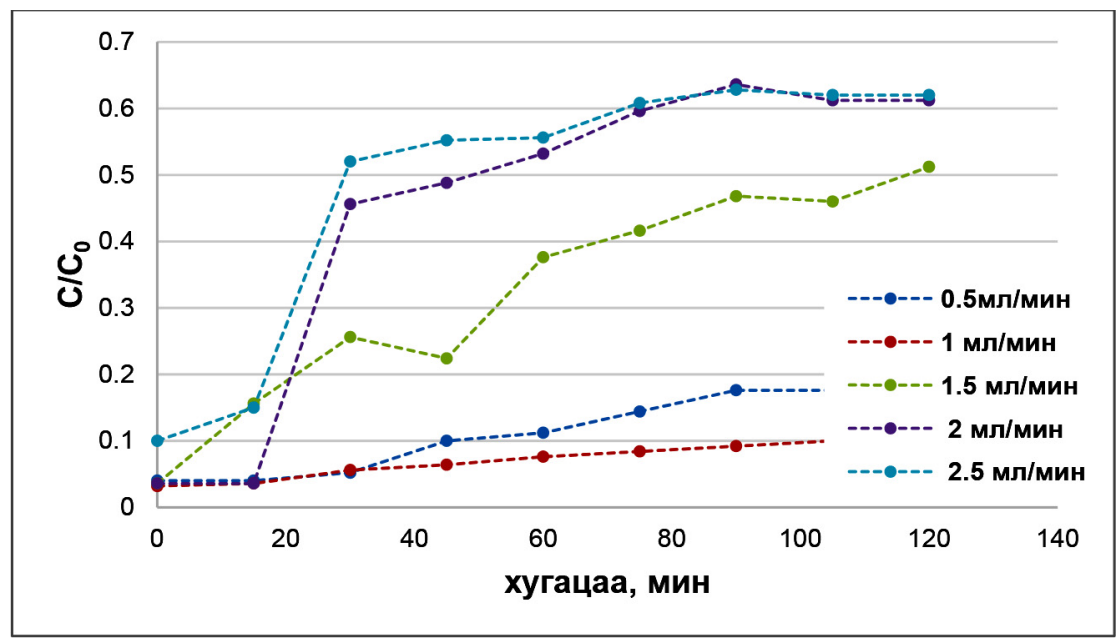

Зураг.3. Уусмал нэвтрэх хурд ялгаатай уед $C / C_{0}$ хугачааны хамаарал $\left(C_{0}=10 \mathrm{Mz} / \mathrm{s}, h=10 \mathrm{~cm}, \theta=20-25^{\circ} \mathrm{C}\right)$

Зураг.3-аас харахад колонк руу уусмал нэвтрэх хурд 0.5-2.5 мл/мин болж ихсэхэд концентрацын харьцаа биосорбцын эхэнд эрчимтэй өсөж, туршилт явуулснаас хойш 40 минут болоход тогтмолжсон. Энэ нь биосорбент материал уусмалаас $\mathrm{Cr}(\mathrm{VI})$ ионыг шингээж, биосорбент материал металл ионоор ханаж байгаатай холбоотой юм. Колонк руу уусмал нэвтрэх хурд ихсэхэд концентрацын харьцаа хугацаа ихсэх тусам өсөж байлаа. Колонк руу уусмал нэвтрэх хурд бага үед биосорбентод металл ионы хуримтлагдах процесс бүрэн явагдаж байгаа нь ажиглагдлаа. Энэ нь уусмал нэвтрэх хурд ихсэхэд бисорбентын гадаргуу дахь металлын ионы диффузлэгдэх хугацаа багасдаг бөгөөд биосорбц бүрэн явагдалгүй системд тэнцвэр тогтдогтой холбоотой юм $[16,17]$. Иймд колонк руу уусмал нэвтрэх хурдыг 1 мл/мин байх нь тохиромжтой гэж үзлээ.

Зохистой нөхцөлд явуулсан туршилтын дүн

Өмнөх туршилтын дүнг үндэслэн усан уусмалаас $\mathrm{Cr}(\mathrm{VI})$ ионыг биосорбцлох туршилтыг уусмалын анхны концентраци 10 мг/л, биосорбентын үеийн зузаан 10 см, уусмал нэвтрэх хурд 1 мл/мин гэсэн нөхцөлд явуулав. Туршилтын дүнг Зураг.4-д харууллаа. 


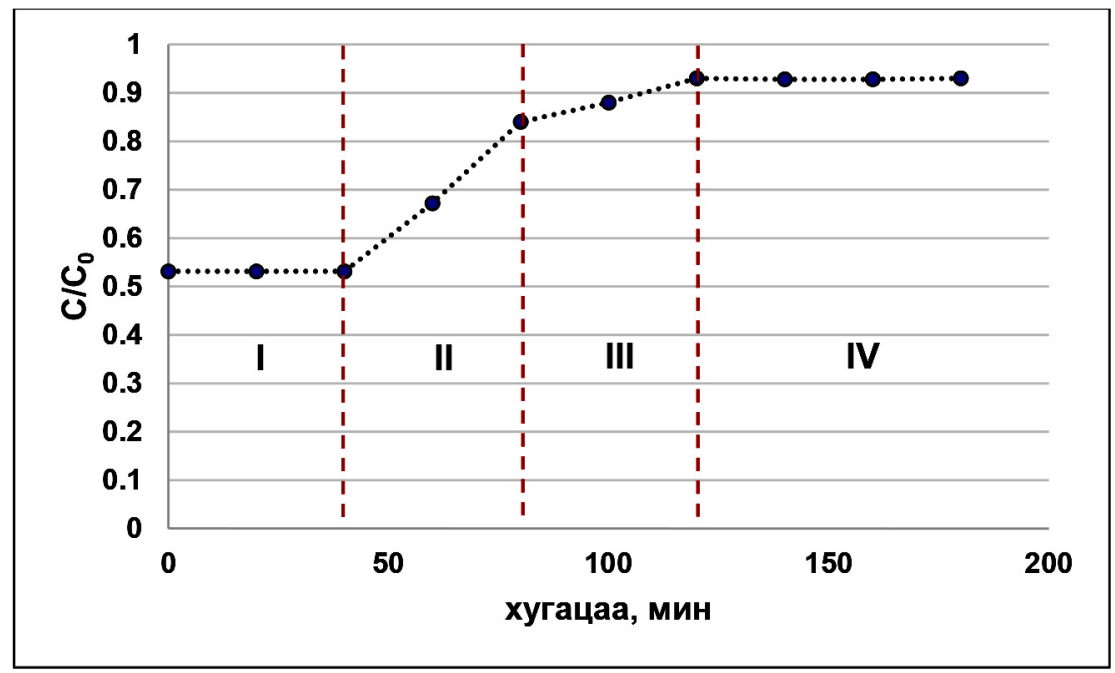

Зураг.4. Зохистой нөхиөлд явуулсан Cr(VI)-ын биосорби $\left(C_{0}=10 \mathrm{Mz} / \mathrm{s}, h=10 \mathrm{~cm}, \mathrm{v}=1 \mathrm{Mл} / \mathrm{мuн}\right)$

Туршилтын дүнг (Зураг 4)-ээс харахад биосорбцын процесс үндсэн 4 үе шаттайгаар явагдаж байна. Эхний 40 минутад биосорбент сорбат гэсэн системд $\mathrm{Cr}(\mathrm{VI})$ ионы шилжилт явагдаж байна. Туршилтын 40-80 минутад $\mathrm{Cr}(\mathrm{VI})$ ион биосорбент (липтон цайны биомасс)-ын гадаргууд диффузлэгдэх ба энэ хоёрдугаар үе шат нь хурд ихтэй явагддаг болох нь харагдсан. Эдгээр I, II шатанд Cr(VI) ион биосорбентын гадаргууд хуримтлагдана. Харин туршилтын 80 дахь минутаас биосорбентын идэвхтэй төв рүY $\mathrm{Cr}(\mathrm{VI})$ ионы шилжилт явагдана. Биосорбцын сүүлийн IV шатанд ион солилцох, комплексжих, тунадасжих зэрэг хэд хэдэн процесс хамт явагдах боломжтой тул металл хуримтлуулах нийлмэл механизмтэй процесс гэж үздэг [1].

Харин 120 дахь минутаас биосорбент $\mathrm{Cr}(\mathrm{VI})$ ионоор бүрэн ханаж, системд биосорбент - сорбат гэсэн хөдөлгөөнт тэнцвэр тогтож байгааг зургаас харж юм. Зохистой нөхцөлд явуулсан биосорбцын концентрацын харьцаа хугацааны хамаарал буюу биосорбцын эргэлтийн муруй нь ерөнхийдөө S хэлбэртэй гарсан нь биосорбц бүрэн гүйцэд явагдсан болохыг илэрхийлж байна $[2,9,15]$.

Динамик нөхцөл дэх биосорбцын кинетикийн судалгаа

Динамик нөхцөлд усан уусмалаас $\mathrm{Cr}(\mathrm{VI})$-ыг биосорбцлох үеийн кинетикийн тооцоог уусмалын анхны концентрацаас хамааруулан явуулсан туршилтын дүнг хэрэглэн pseudo-I, pseudo-II эрэмбийн кинетик загвар тэгшитгэлүүдээр (тэгшитгэл 3 , тэгшитгэл 5) хийлээ. Шугаман хамаарлын графикийг зураг.5-д нэгтгэн харууллаа.

5-p зургаас харахад липтон цайны биомассаар усан уусмалаас $\mathrm{Cr}(\mathrm{VI})$-ыг биосорбцлох процесс нь pseudo-II эрэмбийн зүй тогтлоор явагдаж байгаа нь илэрхий байна. Процесс pseudo-II эрэмбийн кинетик зүй тогтлоор явагдаж байгаа үед сорбатбиосорбентын хооронд химийн харилцан үйлчлэл явагддаг гэж үздэг [1].

Pseudo-I ба pseudo-II эрэмбийн кинетик тэгшитгэлийн шугаман хамаарлын графикаас биосорбцын багтаамж болон хурдын тогтмолуудыг тооцооллоо. Тооцооны дүнг хүснэгт.2-т нэгтгэн харууллаа. 

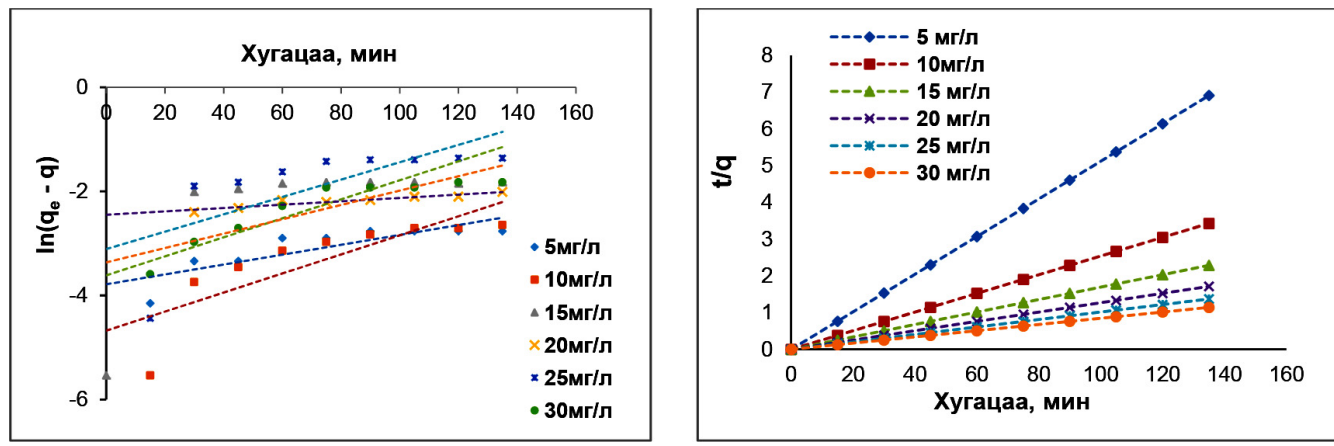

3ураг.5. Уусмалаас Cr(VI)-ыл биосорбилох уеийн рseudo-I, pseudo-II эрэмбийн кинетик муруй $(h=10 \mathrm{~cm}, v=1 \mathrm{мл} /$ мин)

Хуснэгт 2

Pseudo-I болон pseudo-II эрэмбийн урвальн хурдны тогтмолууд

\begin{tabular}{|c|c|c|c|c|c|c|}
\hline \multirow{2}{*}{$\begin{array}{l}\text { Уусмалын анхны } \\
\text { концентраци, мг/л }\end{array}$} & \multicolumn{3}{|c|}{$\begin{array}{c}\text { Pseudo-I эрэмбийн кинетик } \\
\text { тэгшитгэл } \\
\end{array}$} & \multicolumn{3}{|c|}{ Pseudo-II эрэмбийн кинетик тэгшитгэл } \\
\hline & $q_{e^{\prime}}, \mathrm{Mz} / 2$ & $k_{1}, \mathrm{MuH}^{-1}$ & $R^{2}$ & $q_{e}, \mathrm{ML} / 2$ & $k_{2}$, г / (мг мин) & $R^{2}$ \\
\hline 5 & 43.59 & 0.0095 & 0.69 & 19.26 & 1.37 & 0.99 \\
\hline 10 & 105.90 & 0.0183 & 0.67 & 39.21 & 0.800 & 1.00 \\
\hline 15 & 36.74 & 0.0183 & 0.43 & 59.17 & 0.95 & 0.99 \\
\hline 20 & 11.47 & 0.0032 & 0.89 & 78.74 & 0.80 & 1.00 \\
\hline 25 & 22.12 & 0.0167 & 0.48 & 98.03 & 0.34 & 1.00 \\
\hline 30 & 28.58 & 0.0138 & 0.82 & 117.64 & 0.36 & 1.00 \\
\hline
\end{tabular}

Регрессийн коэффициентын утгаас харахад липтон цайны биомассаар $\mathrm{Cr}(\mathrm{VI})$ ыг биосорбцлох процесс нь pseudo-II эрэмбийн кинетик зүй тогтлоор явагдаж байна. Энэ процессын хувьд уусмалын анхны концентраци ихсэхэд pseudo-II эрэмбийн кинетик тэгшитгэлийн хувьд биосорбцын багтаамж 19.5-117.6 мг/г болж өссөн байлаа. Энэ нь уусмалын концентраци ихсэхэд тухайн процессын хурд ихсэх ба биосорбент - сорбатын хоорондын идэвхтэй харилцан үйлчлэл ихсэж байгаатай холбоотой юм. Биосорбцын багтаамж 19.5117.6 мг/г гарсан нь уусмал дахь металл ионы концентрацын нөлөөг судалсан туршилтын дүн (18.86 мг/г-115.94 мг/Г)-тэй тохирч байлаа. Процесс pseudo-II эрэмбийн кинетик зүй тогтлоор явагдаж байгаа үед урвалын хурд тодорхойлох шатанд химийн сорбц буюу сорбат биосорбентын хооронд электроны шилжилт явагддаг $[1,17]$. Харин тухайн процесс pseudo-I эрэмбийн кинетик зүй тогтлоор явагдаж байвал их хурдтай явагдах ба урвалын хурд тодорхойлох шатанд физик сорбц явагдаж, тухайн процесс эргэх шинж чанартай байдаг нь бидний судалгаагаар батлагдлаа $[1,17]$.

\section{Биосорбент}

липтон

цайны биомассын гадаргуугийн шинжилгээ: Биосорбент липтон цайны биомассын гадаргуугийн зургийг МУИС, ХШУСийн Нанотехнологийн лабораторт Semtrac Mini SM3000 маркийн сканнинг электрон микроскопийн багажаар авсан. Судалгаанд хэрэглэсэн биосорбентын гадаргуугийн зургийг (6-р зураг) доор үзүүллээ.

Липтон цайны биомассын биосорбцын өмнөх гадаргуугийн зургаaс харахад гадаргуу барзгар, сүвэрхэг бүтэцтэй байсан. Харин биосорбцын дараа биомассын 
гадаргууд өөрчлөлт орж, сүвэрхэг байдал багассан байлаа. Энэ нь биосорбентын идэвхтэй хэсгүүдтэй металлын ион харилцан үйлчлэлд орж, биосорбентын гадаргууд сууснаар сүвэрхэг байдал нь багассантай холбоотой гэж үзлээ.

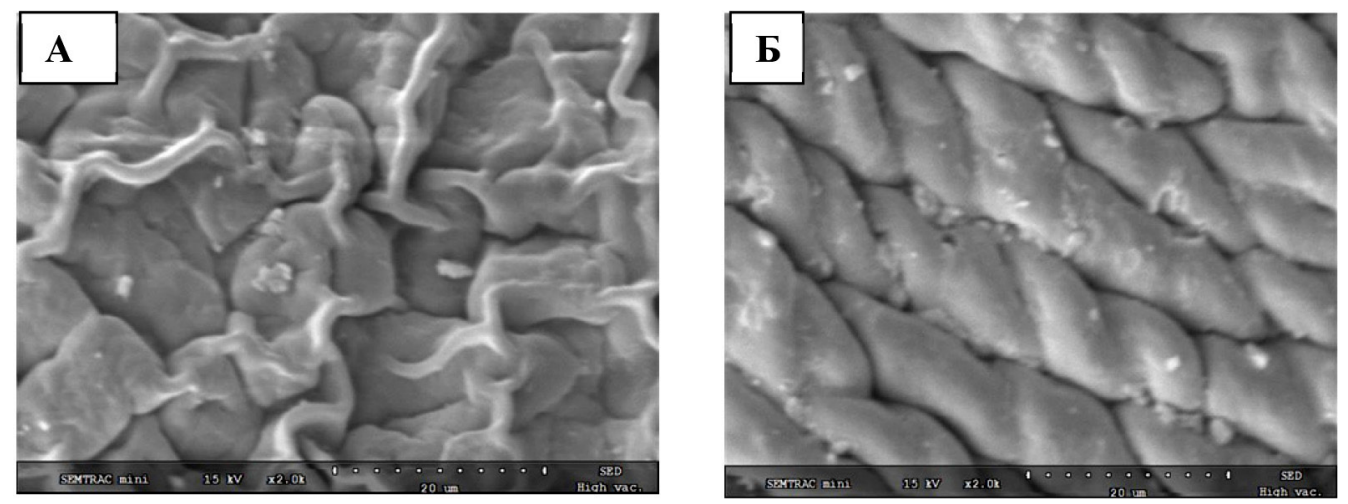

Зураг.6. Биосорбент липтон иайны биомассын гадаргуугийн зураг (А-Биосорбиьын өмнө, Б- Биосорбиын дараа)

\section{ДУГНЭЛТ}

1. Биосорбент липтон цайны биомассын органик биш макрокомпонентын агуулгыг рентгенфлуоресценцийн спектрометрээр тодорхойлоход $\mathrm{MgO}$ $0.56 \%, \quad \mathrm{Na}_{2} \mathrm{O}-0.02 \%, \quad \mathrm{~K}_{2} \mathrm{O}-0.2 \%$, $\mathrm{CaO}-$ $54.9 \%$ агуулагдаж байлаа. Иймд усан уусмалд анионы хэлбэр $\left(\mathrm{CrO}_{4}^{2-}, \mathrm{HCrO}_{4}^{-}\right)$ээр агуулагдах $\mathrm{Cr}(\mathrm{VI})$ ионтой биосорбент материалд агуулагдах кальци ба магнийн ион харилцан үйлчлэлд орох боломжтой юм.

2. Динамик нөхцөлд липтон цайны биомассаар усан уусмалаас $\mathrm{Cr}(\mathrm{VI})-$ ыг биосорбцлох процессыг уусмалын анхны концентраци-10 мг/л, биосорбентын үеийн зузаан 10 см, уусмал нэвтрэх хурд 1 мг/мин үед явуулах нь тохиромжтой гэж үзлээ.

3. Динамик нөхцөл дэх биосорбцын кинетик тооцоогоор pseudo-II эрэмбийн хурдны тогтмол нь 0.34-1.36 г/(мг×мин) байлаа. Энэ процесс нь pseudo-II эрэмбийн кинетик зүй тогтлоор буюу биосорбцын сүүлийн шатанд химийн харилцан үйлчлэл явагдаж байгаа тул усан уусмалаас $\mathrm{Cr}(\mathrm{VI})$-ыг липтон цайны биомассаар биосорбцлох бүрэн боломжтой болохыг тогтоолоо.

\section{Аиигласан бутээлийн жагсаалт}

1. Алтангэрэл.А, 2011, Усан уусмалаас хром, хар тугалганы агуулгыг биосорбиын аргаар багасгах прочессын физик химийн судалгаа, Докторын зэрэг горилсон судалгааны ажил, УБ, х.40-83

2. Suleman Qaiser, Anwar Rasheed Saleemi, Muhammad Umar, 2009, Biosorption of lead from aqueous solution by Ficus religiosa leaves: Batch and column study, Journal of Hazardous Materials 166: 998-1005

3. Suhong Chen, Qinyan Yue, Baoyu Gao, Qian Li, Xing Xu, Kaifang Fu, 2012, Adsorption of hexavalent chromium from aqueous solution by modified corn stalk: A fixed-bed column study, Bioresource Technology 113: 114-120

4. Уснь чанар - Хром (VI) тодорхойлох 1,5-дифенилкарбазид ашигласан 
спектрометрийн арга, MNS ISO 11083-2001, Монгол Улсын Үндэсний стандарт

5. Kratochvil. D, Volesky. B., 1998, Advances in the biosorption of heavy metals, Trends Biotechnology, 16: 291-300

6. Volesky. B, 2007, Biosorption and me: review, Water Research, 41: 4017-4029

7. Gokhale. S. V, Jyoti. K. K, Lele. S. S, 2009, Modeling of chromium(VI) biosorption by immobilized Spirulina platensis in packed column, Journal of Hazardous Materials, 170:735-743

8. Fabrianto. J, Kosasih. A. N, Sunarso. J, Ju. Y, Indraswati. N, Ismadji. S, 2009, Equilibrium and kinetic studies in adsorption of heavy metals using biosorbent: A summary of resent studies, Journal of Hazardous Materials, 162:616-645

9. Plazinski. W, Rudzinski. W, Plazinska. A, 2009, Theoretical models of sorption kinetics including a surface reaction mechanism: A review, Advances Colloid Interface Science, 152:2-13

10. Ho. Y. S, McKay. G, 2006, Pseudo-second order model for sorption processes, Process Biochemistry, 34: 451-465

11. Liu. Y, Shen. L, 2008, A general rate law equation for biosorption, Biochemistry Engineering Journal, 38:390-394

12. Liu. Y, Liu. Y. J, 2008, Biosorption isotherms, kinetics and thermodynamics, Seperation and Purification Technology, 61:229-242

13. Schiewer. S, Balaria. A, 2009, Biosorption of Pb2+ by original and protonated citrus peels: Equilibrium, kinetics and mechanism, Chemical Engineering Journal, 146:211219

14. Febrianto. J, 2009, Equilibrium and kinetic studies in adsorption of heavy metals using biosorbent: A summary of recent studies, Journal of Hazardous Materials, 162:616645

15. Naddafi. K, Nabizadeh. R, Saeedi. A, 2006, Biosorption of lead(II) and cadmium(II) by protonated Sargassum glaucescens biomass in a continuous packed bed column, Journal of Hazardous Materials, 147:785-791

16. Dabrowski. A, 2001, Adsorption from theory to practice, Advances in Colloid and Interface Science, 93:166-167

17. Naja. G, Volesky. B, 2008, Biosorption, metals, Encyclopedia of Industrial Biotechnology, 6: 196-211 


\title{
KINETIC STUDY ON BIOSORPTION OF Cr(VI) FROM AQUEOUS SOLUTION IN DYNAMIC CONDITION
}

\author{
A.Altangerel, S.Davaasuren \\ Department of Chemistry, School of Arts and Science, NUM, Mongolia \\ E-mail:dakamuis@yahoo.com
}

\begin{abstract}
Metals containing wastes are directly or indirectly discharged into the environment, especially in the developing countries, having brought a serious environmental pollution, and threatened to biolife. Among biological, physical and chemical methods of polluting heavy metals removal and their compounds, biosorption method is considered to be economically cheap and environmentally friendly as well as high productivity. The biosorption kinetic of $\mathrm{Cr}(\mathrm{VI})$ on Lipton tea biomass were investigated with respect to initial $\mathrm{Cr}(\mathrm{VI})$ concentration, flow rate and biosorbent bed height. The $\mathrm{Cr}(\mathrm{VI})$ biosorption from aqueous solutions by Lipton tea biomass was performed in dynamic condition. The highest biosorption capacity of $\mathrm{Cr}(\mathrm{VI})$ by Lipton tea waste was observed at the initial $\mathrm{Cr}(\mathrm{VI})$ concentration of $10 \mathrm{mg} / \mathrm{l}$, flow rate $1 \mathrm{ml} / \mathrm{min}$ and biosorbent bed height $10 \mathrm{~cm}$. Biosorption of $\mathrm{Cr}$ (VI) was followed with the pseudo-II kinetics.
\end{abstract}

Keywords: biosorption, dynamic condition, Cr(VI), lipton tea biomass, kinetic study 